\title{
The performance of transnational corporations: Evidence for the manufacturing industry in Chile
}

\author{
Sebastián Vergara $M$.
}

ABSTRACT

This article analyses the performance of transnational corporations in Chilean manufacturing industry. The findings show that while the productivity of subsidiaries of foreign-owned firms is higher than that of local firms, the same is not true of productivity growth. They also show that there are no significant differences in market survival rates between transnational corporations and local firms. However, firms under mainly foreign ownership that are small and have low productivity are more likely to exit the market, displaying more footloose behaviour than their local counterparts. This is associated with lower levels of profitability for this group of transnational firms. Lastly, the findings suggest that transnational corporations are not always more profitable than local firms. Furthermore, they seem able to exploit their advantages over the latter only in the higher quantiles of the profitability distribution.

KEYWORDS

JEL CLASSIFICATION

AUTHOR
Transnational corporations, industry, manufactures, productivity, profitability, evaluation, statistical data, Chile

L25, F23, C21

Sebastián Vergara M. is an Economic Affairs Officer at the United Nations Department of Economic and Social Affairs (DESA). vergaras@un.org 


\section{I}

\section{Introduction}

In recent decades, transnational corporations have become important global players in trade, innovation, technology and value chains, and key actors in many countries' development (Cohen, 2007; UNCTAD, 2005; Narula and Lall, 2006). One of the most widely accepted theories about the phenomenon of transnational corporations is that they enjoy advantages of ownership, location and internationalization (Dunning, 2000). ${ }^{1}$ The direct implication is that the subsidiaries of transnational corporations should perform better than local firms in the host economies, in terms of productivity and profitability for example, because of their higher levels of technology, capabilities and know-how in international markets.

These considerations need to be treated with caution, however, as foreign ownership does not in itself guarantee a better performance than that of local firms. First, the subsidiaries of transnational corporations, like local firms, constitute a large and heterogeneous array of businesses with differing characteristics and capabilities. Second, there are factors that can negatively affect the performance of transnational corporations, such as lack of experience in the local market and inadequate knowledge of competition patterns. Indeed, this can be a particularly important factor in developing countries that have specific characteristics as regards suppliers, infrastructure, labour markets and informality. Third, it can be seen from the recent literature that the flow of knowledge in a transnational corporation is a complex and demanding process, and it cannot be assumed that knowledge will move freely between the parent firm and its subsidiaries. In other words, the advantages of ownership by transnational corporations could be confined to their more advanced production operations. For example, Hobday and Rush (2007) stress the degree of autonomy subsidiaries have and their integration into corporate strategies that are decentralized from the parent companies as aspects that determine the flow of knowledge between a parent company and its subsidiaries. Marín and Arza (2009) discuss the role played by the latter in terms of their ability to interconnect two knowledge networks, the global one and the national one. These factors call

The author is grateful for the comments of Miguel Torres and an anonymous referee.

1 See Caves (1996) and Markusen (2002) for an overview of the literature on transnational corporations. into question the assumption that the subsidiaries of transnational corporations will necessarily have a better production performance than local firms.

In Latin America there is a substantial literature on foreign direct investment (FDI) and transnational corporations, particularly as regards sectors of operation, activity types, modes of entry and corporate strategies that explain their regional positioning (ECLAC, 2012; ${ }^{2}$ Gallagher and Chudnovsky, 2009; Moran, Graham and Blomström, 2005). However, there is little information about the production activities of transnational corporations based on performance indicators comparable to those for local firms. Furthermore, such evidence as does exist is usually confined to a small group of large transnational corporations operating in oligopolistic service markets with high levels of concentration, such as energy and telecommunications, where regulation plays a particularly important role in competition patterns and profitability. It is important to look more closely at this aspect, given the role played by these firms in shaping the production mix of the region's countries, something that is also crucial for understanding their potential effects on the host economies. Indeed, there is a huge literature examining the effects the activities of transnational corporations have on host economies, particularly as regards linkages, technology transfers and the creation and enhancement of local capabilities in developing countries. Nonetheless, the evidence is mixed and often contradictory. It seems that the effects depend not only on the characteristics of transnational corporations in terms of corporate strategies, sectors and types of production and service activity, but also on the absorption capacity of economies (Lipsey, 2002; Moran, Graham and Blomström, 2005). ${ }^{3}$

\footnotetext{
2 See the various editions of Foreign Direct Investment in Latin America and the Caribbean, published annually by the Division of Production, Productivity and Management of ECLAC.

3 The effects of transnational corporations' operations may be direct or indirect. The direct effects are those that do not depend particularly on the interaction between transnational corporations and absorption capacity. Among these, mention may be made of greater access to foreign currency, increased gross fixed capital formation, increased supply (greater production of and access to goods and services and increased employment) and effects associated with higher exports and potential environmental repercussions. The indirect effects, meanwhile, are determined by the absorption capacity of the host country: human capital, the capabilities of the technology base, infrastructure, local
} 
This article analyses the performance of transnational corporations' subsidiaries relative to local firms in the Chilean manufacturing sector, on the basis of three indicators: productivity, market survival and profitability. ${ }^{4}$

suppliers, the production mix and the national innovation system. Among these effects, mention may be made of production linkages, technology transfer and the creation and enhancement of local capabilities (ECLAC, 2011, p. 27).

4 A complementary examination of firms' productivity and profitability is justified by the fact that they are used to measure different operational aspects. On the one hand, productivity is more closely associated with technical and production aspects, linking output to a particular level of inputs. Profitability, on the other hand, ties in with economic and
The study is organized as follows. Section II briefly reviews the literature and section III sets out some general characteristics of the presence of transnational corporations in Chilean manufacturing industry. Then section IV describes the different empirical methodologies and section $\mathrm{V}$ discusses the results of the estimations. Lastly, section VI presents the main conclusions.

financial aspects via revenues and operating costs. The correlation between the two variables shows that productivity increases translate to some degree into higher profitability, but this is not necessarily always the case. Most private firms focus exclusively on maximizing the profitability of their operations.

\section{II}

\section{A brief review of the literature}

There are a number of studies comparing the performance of transnational corporations with that of local firms, especially in developed countries. In terms of productivity, on which there is a relatively extensive literature, particularly for the manufacturing sector, there is ample evidence that the advantages enjoyed by transnational corporations, whether foreign-owned or domestically owned, ${ }^{5}$ make them more productive than local firms. This has been confirmed using different measures, such as indicators of technical efficiency, labour productivity or total factor productivity (TFP). For example, Baldwin, Lipsey and Richards (1998) point out that the subsidiaries of transnational corporations in the United States are more capital-intensive, pay higher wages and have higher labour productivity, even when factors such as size, sector and so on are controlled for. Temouri, Driffield and Higón (2008) analyse TFP in Germany in the 1995-2004 period. Using semiparametric evidence to control for endogeneity problems, the authors show that the fact of being a transnational firm (whether domestically owned or foreign-owned) goes a long way towards explaining productivity differences between firms.

Likewise, Girma, Kneller and Pisu (2005) have shown for the United Kingdom that both the subsidiaries of transnational corporations and British transnationals are more productive than exporting firms, which in turn are more productive than non-exporting firms. ${ }^{6}$ Thus, a

\footnotetext{
5 Domestically owned transnational corporations are local firms carrying out operations in international markets.

6 Dimelis and Louri (2002) present efficiency estimates for industry in Greece. Their findings show that firms under majority foreign ownership have the highest productivity.
}

distinction is made in the literature on developed countries between transnational corporations (foreign or local) and purely domestic firms, largely because many local firms carry out international operations.

In a developing country context, Blomström and Sjöholm (1999) present similar evidence for manufacturing industry in Indonesia, where transnational corporations have higher labour productivity and local firms benefit from productivity spillovers. However, the degree of foreign ownership at the firm level does not seem to affect the results. In Latin America, Blomström (1988) analyses labour productivity in Mexican manufacturing industry. His findings reveal that the subsidiaries of transnational corporations are more productive because of specific advantages in terms of capabilities and know-how, i.e., ownership advantages. In a more recent analysis, Álvarez and Crespi (2007) examine the case of Chilean industry during the 1979-2000 period. Their findings reveal that transnational corporations have higher TFP and, furthermore, are important agents in technology transfer; consequently, their presence is favourable to productivity catch-up at local firms.

In terms of market survival, there are opposing theoretical arguments regarding the performance of transnational corporations. On the one hand, the subsidiaries of transnational corporations might be more likely to exit the market because, in an economic crisis, they can shift or alter operations across different production locations via the transnational corporation's international production system. This may be more clearly the case if the subsidiary has few linkages with the local economy. Thus, in a local economic crisis, the 
subsidiaries of transnational corporations may have a greater proclivity to exit the market than local firms. For example, Bandick (2010) studies the survival of transnational corporations in Swedish industry. The findings suggest that these firms really are more likely to exit the market than local firms. However, when firms are differentiated by export activity, transnational corporations have higher survival rates than local firms that do not export, while survival rates for transnational corporations and local exporters are not significantly different. Similarly, Görg and Strobl (2003) and Bernard and Sjöholm (2003) show that transnational corporations are more likely to exit than domestic firms in Ireland and Indonesia, respectively. For Chile, Álvarez and Görg (2009) indicate that domestic market-oriented subsidiaries of transnational corporations were also more likely to exit in the 1990s than their local counterparts.

On the other hand, subsidiaries of transnational corporations may present a lesser likelihood of exit (i.e., higher survival rates) insofar as they have greater sunk costs and operating projects whose returns lie in the medium term. This could be particularly the case if an economic crisis is believed to be temporary. While there are no empirical studies to confirm this, it has been shown that local and transnational firms can behave similarly. In a recent study, Godart, Görg and Hanley (2011) find that firms with different ownership situations in Ireland did not behave heterogeneously in the face of the 2008 economic crisis. In other words, while exit rates increased across the board, transnational corporations were not a cause of particular instability in the economy. Mata and Portugal (2002) note that, after controlling for different variables at the firm and industry level, transnational and local firms in Portuguese industry do not behave very differently in terms of survival.

Lastly, studies on profitability differences between transnational and local firms are scarce and report mixed results. On the one hand, some studies show that the advantages of transnational corporations do in fact translate into higher profitability. For example, Benvignati (1987) shows that transnational corporations in the United States are more profitable on average than domestic firms, and the findings are statistically robust when different measures of foreign ownership are considered. Kumar (1990) analyses the manufacturing sector in India. His findings also suggest that transnational corporations do indeed perform better than local firms, especially in knowledge-intensive sectors. This seems to be related to the fact that these sectors can take advantage of knowhow and capabilities accumulated, for example, through past investments in research and development (R\&D). Ramstetter (1998) likewise examines the importance of transnational corporations in a number of Asian economies. His findings show, among other characteristics, that transnational corporations have higher levels of profitability, in Singapore for example. Conversely, Barbosa and Louri (2005) study the cases of Portugal and Greece in the 1990s. In the case of Portugal, the results indicate that foreign ownership is not associated with significant differences in profitability. By contrast, in Greece profitability differences between domestic and foreign firms appear only in the upper quintiles of the profitability distribution.

\section{III}

\section{Data and stylized facts}

In the past few decades, a development model based on market opening and deregulation with a heavy predominance of the private sector in production activities has been implemented in the Chilean economy. In this context, foreign direct investment (FDI) has become a cornerstone of the development strategy, and a legal framework with strong guarantees for foreign capital has been established. Indeed, Chile stands out among Latin American countries as one of the most important destinations for FDI in the last decade, both in absolute terms and in relation to the size of its economy (ECLAC,
2012 and 2001). ${ }^{7}$ Transnational corporations have thus come to form a group of agents with a presence in most production and service activities. They have only a relatively small presence in manufacturing, however, by comparison with the primary and service sectors, where

\footnotetext{
7 FDI in Chile averaged US\$ 5.4 billion a year during 2000-2006 and over US\$ 15 billion during 2006-2011. In recent years, the ratio of FDI to gross domestic product (GDP) has been over $8 \%$, one of the highest among the larger economies of Latin America (ECLAC, 2012).
} 
most FDI has gone. Between 2005 and 2010, 92\% of FDI went to natural resource and service sectors, with just $7 \%$ going to manufacturing (ECLAC, 2012). The inward FDI share of the manufacturing sector in Chile was greater between 1996 and 2005, at about 11\% (ECLAC, 2006).

The information source used to analyse the performance of transnational corporations in the Chilean manufacturing sector is the National Institute of Statistics (INE) Annual National Industry Survey (ENIA) for the 2001-2006 period. This survey collects information at the manufacturing plant level on production, value added, sales, employment, ownership, wages, exports, investment and energy use, among other variables. Sectoral deflators provided by INE were used to convert the monetary variables to constant 2003 pesos. For each year, the survey compiles information on some 4,500 manufacturing plants, which are also classified at the sector level using the International Standard Industrial Classification of All Economic Activities (ISIC).

From the ENIA information it can be seen that transnational corporations account for a relatively low share of aggregate employment but a considerably greater share of value added, sales and, especially, exports. In 2006, manufacturing firms under foreign ownership accounted for $30 \%$ of value added and $45 \%$ of industrial exports, but just $17 \%$ of employment (see figure 1). Transnational corporations' shares of employment, value added and sales had held steady or were slightly down on the start of the decade. Their share of exports had risen strongly, however, from 34\% in 2001 to $45 \%$ in 2006. Thus, as the country has become more integrated into the international economy, transnationals have become more important to exports, probably by exploiting their larger scales of operation, their more advanced technology and their greater knowledge of external markets. ${ }^{8}$

The characteristics of industrial sectors play an important role in the sectoral positioning of transnational firms. Key aspects are capital intensity, sunk costs, optimum plant size and technology patterns in each sector. Thus, the sectors with the greatest presence of transnationals, in terms of value added, are the tobacco, plastics, non-ferrous metals, transport equipment and scientific and professional control equipment industries. In these sectors, foreign-owned firms account for over $50 \%$ of sectoral value added. Conversely, there is only a small

8 Álvarez and López (2008) show that the export activity of transnational corporations in the Chilean manufacturing sector generates major productivity spillovers, both towards suppliers and customers and towards other plants in the same sector.

FIGURE 1

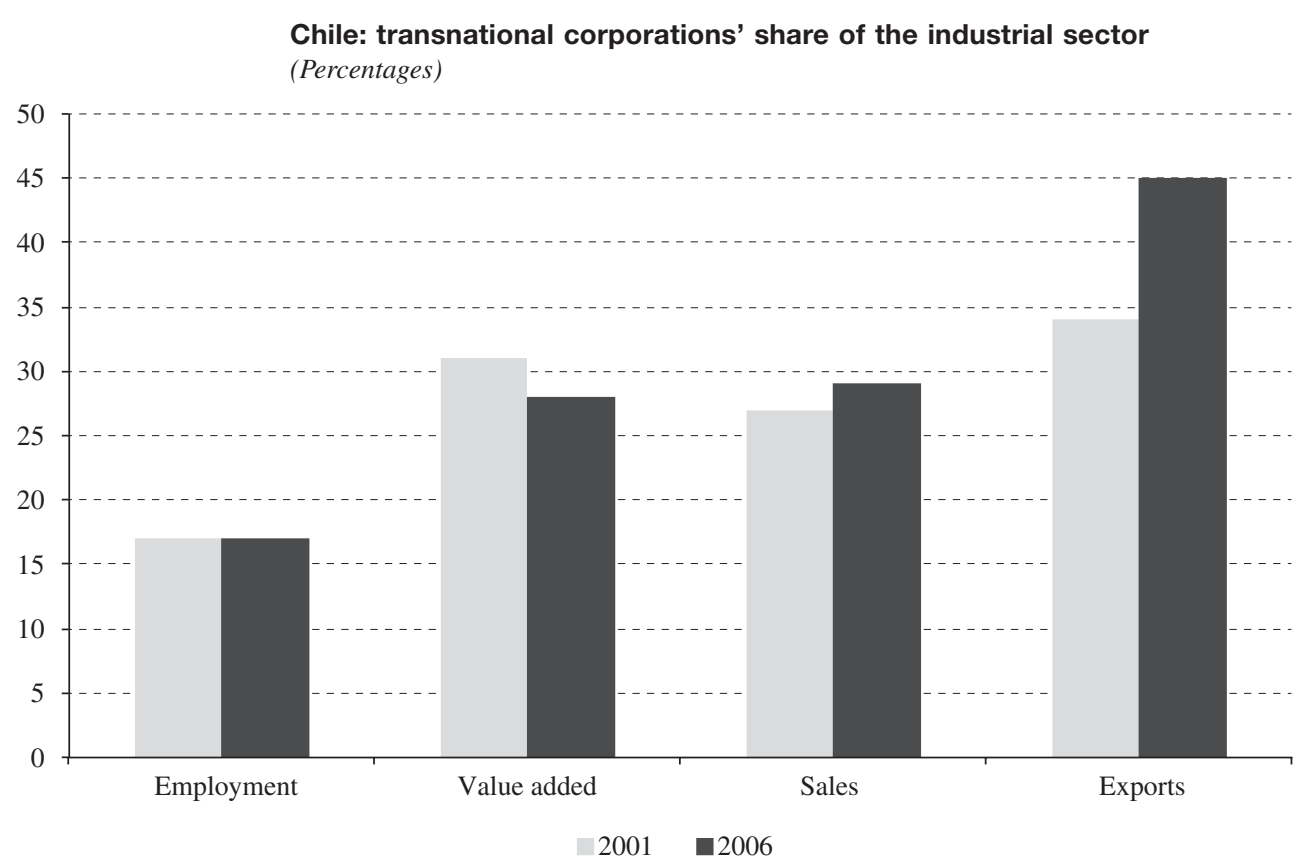

Source: prepared by the author on the basis of the Annual National Industry Survey (ENIA), 2001-2006. 
proportion of foreign ownership in more labour-intensive sectors, including in particular the leather, furniture, textile and wearing apparel industries. Transnational corporations' share of sectoral value added is below $10 \%$ in these sectors.

At a more disaggregated level, transnational corporations differ from local firms in various respects. Table 1 gives an overview of some differences between the two groups of firms in Chilean manufacturing industry. It can be seen that transnational manufacturing firms are substantially larger than local ones, invest more on average in physical capital and have a slightly higher level of capabilities in their workforces. Transnational corporations are also more oriented towards external markets: in the period of analysis, over $60 \%$ of transnational corporations exported at some time or other. Furthermore, while local firms carrying out exports made just $6 \%$ of their sales on average in external markets, the figure was $28 \%$ for transnational corporations.

With regard to performance, a preliminary exercise is to observe average values for labour productivity (defined as value added over the number of employees), market survival and profitability by firm type. Labour productivity is higher in transnational firms, something that has been amply documented in the literature, as discussed in the previous section. Survival rates are likewise higher for transnational firms than for local ones, which appears to indicate that they are better placed to cope with fluctuations in the business cycle owing, for example, to economies of scale and, probably, better financing conditions. Lastly, transnational corporations appear to have higher levels of profitability. For local firms, the index of earnings before taxes, depreciation and amortization over sales is $24 \%$, while for transnational corporations it is $30 \%$ (see table 1 ).

Thus, the preliminary descriptive analysis tends to confirm a priori expectations about the behaviour of transnational corporations relative to local firms: they are larger, invest more in fixed capital and have higher employee skill levels, while in terms of performance they have greater productivity, survival rates and profitability. Section IV analyses these differences in greater depth.

TABLE 1

Chile: characteristics of manufacturing firms by ownership, 2001-2006

\begin{tabular}{|c|c|c|c|c|}
\hline \multirow[t]{2}{*}{ Variable } & \multicolumn{2}{|c|}{$\begin{array}{c}\text { Local } \\
(7333 \text { different firms }) \\
(n=28 \text { 871) }\end{array}$} & \multicolumn{2}{|c|}{$\begin{array}{c}\text { Transnational } \\
\text { (549 different firms) } \\
(n=1950)\end{array}$} \\
\hline & Mean & Standard deviation & Mean & Standard deviation \\
\hline Size & 66.54 & 144.9 & 208.77 & 343.8 \\
\hline Investment & 0.07 & 0.15 & 0.09 & 0.14 \\
\hline Skills & 0.41 & 0.31 & 0.44 & 0.30 \\
\hline Exports & 0.17 & 0.37 & 0.61 & 0.48 \\
\hline Export orientation & 0.06 & 0.20 & 0.28 & 0.36 \\
\hline Labour productivity & 9.02 & 1.09 & 10.37 & 1.38 \\
\hline Survival & 0.89 & 0.30 & 0.92 & 0.26 \\
\hline EBITDA & 0.24 & 0.19 & 0.30 & 0.23 \\
\hline
\end{tabular}

Source: prepared by the author on the basis of the Annual National Industry Survey (ENIA), 2001-2006.

Note: explanatory variables: Size: number of employees. Investment: ratio between physical capital investments and capital stock. Skills: ratio between numbers of skilled and unskilled employees. Exports: average dichotomous variable taking the value 1 if the firm exports and 0 otherwise. Export orientation: percentage of sales made abroad. Labour productivity: ratio between value added and number of employees. Survival: likelihood of a firm observed in the market at time $t$ also being there at $t+1$. EBITDA: earnings before interest, taxes, depreciation and amortization as a percentage of sales.

$n=$ number of firms. 


\section{IV}

\section{Empirical strategy}

\section{Productivity}

Productivity is analysed on the basis of total factor productivity (TFP). TFP is calculated using the methodology proposed by Olley and Pakes (1996) as modified by Levinsohn and Petrin (2003). Thus, a CobbDouglas production function is estimated for each sector at the three-digit level of ISIC using the following equation:

$$
y_{i t}=\beta_{0}+\beta_{1} K_{i t}+\beta_{2} L_{i t}^{s}+\beta_{3} L_{i t}^{u}+\varepsilon_{i t}
$$

where $y_{\text {it }}$ is the logarithm of the value added of firm $i$ at time $t, \mathrm{~K}_{\mathrm{it}}$ is the logarithm of the capital stock and $\mathrm{L}_{\text {it }}^{\mathrm{s}}$ and $\mathrm{L}^{\mathrm{u}}{ }_{\text {it }}$ are the logarithms of the number of skilled and unskilled workers, respectively. TFP is then defined as:

$$
\mathrm{TFP}=\exp \left(\mathrm{y}_{\mathrm{it}}-\beta_{1} \mathrm{~K}_{\mathrm{it}}-\beta_{2} \mathrm{~L}_{\mathrm{it}}^{\mathrm{s}}-\beta_{3} \mathrm{~L}_{\mathrm{it}}^{\mathrm{u}}\right)
$$

If the error in equation (1) is not correlated with the explanatory variables, the production function can be estimated directly using ordinary least squares (OLS). However, it is usual to expect the error term $\varepsilon_{\text {it }}$ to be correlated with the explanatory variables, since productivity is observed by the firm managers, who also take the decisions about the use of inputs in production. According to Olley and Pakes (1996) and Levinsohn and Petrin (2003), the production function is estimated with explicit reference to this problem of endogeneity. For this, it is assumed that $\varepsilon_{i t}=\omega_{i t}+\eta_{i t}$, where $\omega_{\mathrm{it}}$ reflects the correlation with productivity, and that $\eta_{\mathrm{it}}$ is an error term which is not correlated with production input decisions. It is likewise assumed that $m_{\mathrm{it}}=m_{\mathrm{it}}\left(k_{\mathrm{it}}, \omega_{\mathrm{it}}\right)$, where $\mathrm{m}_{\mathrm{it}}$ are the intermediate inputs used in the production process. Levinsohn and Petrin (2003) show that this ratio is monotonically increasing in $\omega_{\text {it }}$, so that the intermediate inputs function can be inverted to get $\omega_{\mathrm{it}}=m_{\mathrm{it}}\left(k_{\mathrm{it}}, m_{\mathrm{it}}\right)$. Thus, the production function to be estimated is specified as follows:

$$
\begin{gathered}
\mathrm{y}_{\mathrm{it}}=\Phi\left(\mathrm{K}_{\mathrm{it}}, \mathrm{m}_{\mathrm{it}}\right)+\beta_{2} \mathrm{~L}_{\mathrm{it}}^{\mathrm{s}}+\beta_{3} \mathrm{~L}_{\mathrm{it}}^{\mathrm{u}}+\eta_{\mathrm{it}} \\
\Phi\left(\mathrm{K}_{\mathrm{it}}, \mathrm{m}_{\mathrm{it}}\right)=\beta_{0} \beta_{1} \mathrm{~K}_{\mathrm{it}}+\mathrm{m}_{\mathrm{it}}\left(\mathrm{K}_{\mathrm{it}}, \mathrm{m}_{\mathrm{it}}\right)
\end{gathered}
$$

Equation (3) is estimated using electricity consumption as an intermediate input, which means that capital elasticity can be identified, correcting the simultaneity bias. Once TFP has been estimated for each firm and for the different years of the analysis period, a test of means (or of heterogeneous variances between groups of companies) and the Kolmogorov-Smirnov test are carried out to analyse whether the productivity distributions by firm type, in both levels and differences, are similar. Likewise, the following regression model is specified in levels and differences to analyse these hypotheses:

$$
\begin{gathered}
\operatorname{TFP}_{\mathrm{it}}=\theta \mathrm{X}_{\mathrm{it}}+\mathrm{d}_{\mathrm{j}}+\mathrm{d}_{\mathrm{t}}+\varepsilon_{\mathrm{ijt}} \\
\Delta \mathrm{TFP}_{\mathrm{it}}=\theta \mathrm{X}_{\mathrm{it}}+\mathrm{d}_{\mathrm{j}}+\mathrm{d}_{\mathrm{t}}+\varepsilon_{\mathrm{ijt}}
\end{gathered}
$$

The vector of variables $\mathrm{X}$ is composed of different explanatory variables: firm size (number of employees), investments (ratio between fixed capital investments and the capital stock) and labour skills (ratio between numbers of skilled and unskilled employees). Also included are two dichotomous variables that control for the fact of being a transnational corporation and for exporter status. ${ }^{9}$ A priori, these variables can affect productivity both in levels and in differences. The variables $d_{j}$ and $\mathrm{d}_{\mathrm{t}}$, meanwhile, are dichotomous variables that control for specific effects at the sector level (three-digit ISIC) and by year, respectively. The estimation of equations (5) and (6) is implemented using oLs. ${ }^{10}$

\section{Survival}

To analyse survival patterns, and the influence of foreign ownership in particular, the following Probit model is estimated:

\footnotetext{
9 Some studies have shown that the matter of who owns a transnational is also relevant to its operations in other countries. For example, Crespi, Criscuolo and Haskel (2006) analyse the performance of firms in the United Kingdom and show that the ways in which United States multinationals organize work and use information technology make them more flexible and thus more productive than their European counterparts. Unfortunately, information by country on foreign ownership is not available in the Chilean Annual National Industry Survey (ENIA).

10 Table A.1 presents the correlation matrix for the explanatory variables used in the estimates.
} 


$$
\operatorname{Pr}\left(\operatorname{survival}_{\mathrm{ijt}}\right)=\mathrm{f}\left(\alpha+\beta \mathrm{X}_{\mathrm{it}}+\gamma \mathrm{Z}_{\mathrm{jt}}+\mathrm{d}_{\mathrm{j}}+\mathrm{d}_{\mathrm{t}}+\varepsilon_{\mathrm{ijt}}\right)
$$

where $\operatorname{Pr}\left(\right.$ survival $\left._{\mathrm{ijt}}\right)$ is the survival probability of firm $i$ operating in sector $j$ at time $t ; \mathrm{X}_{\mathrm{it}}$ is a vector of variables that control for various firm-level characteristics; and $\mathrm{Z}_{\mathrm{jt}}$ is a vector of variables that control for characteristics at sectoral level. Similarly, $d_{j}$ and $d_{t}$ are dichotomous variables that control for specific effects by sector (three-digit level of ISIC) and by period, respectively. In accordance with the survival literature (Audretsch and Mahmood, 1995; Doms, Dunne and Roberts, 1995; Bernard and Sjöholm, 2003), the vector of variables X includes specific firm-level variables that are expected a priori to affect the survival of a company. Thus, firm size (number of employees), productivity (using the TFP measure), investment (investments in fixed capital formation over capital stock) and labour skills (ratio between numbers of skilled and unskilled employees) are incorporated as explanatory variables.

Also included is a dichotomous variable that controls for foreign ownership of the firm. This variable tests the correlation between foreign ownership and the probability of firm survival. On the one hand, transnational corporations may have advantages associated with greater know-how and technology, and also greater sunk costs, which could make them less likely to exit the market, especially when there is a temporary shock. On the other hand, it may happen that transnational corporations have little knowledge of the local market, while benefiting from international production networks. In this case, such firms can decide to exit the market quickly if difficulties arise and move operations to other locations. Accordingly, transnational corporations may be especially sensitive to short-term returns and behave in a footloose way. ${ }^{11}$

It could also be argued that the mobility of transnational corporations depends on the amount of intangible assets they have invested in their local operation (sunk costs). Thus, survival rates in knowledge-intensive sectors could differ from those in more traditional sectors, such as those based on natural resources or labour. To test the hypothesis that transnational corporations can have different survival rates depending on the type of sector they operate in, the estimates also include dichotomous variables that control for sectors being labour-, natural resource- or knowledge-intensive. ${ }^{12}$ The correlation

\footnotetext{
11 "Footloose" firms are those that have a tendency to relocate their production operations geographically as a strategic response in their international positioning.

12 The classification of natural resource-, labour- and knowledgeintensive sectors was carried out in the light of the typology discussed in Cimoli and others (2005).
}

between foreign ownership and firm survival in different operating sectors is calculated by exploiting the nonlinearity of the Probit model.

The $\mathrm{Z}_{\mathrm{jt}}$ vector incorporates three variables that control for market structure at the sector level. Thus, average firm size and the Herfindahl-Hirschman index of market concentration are included as explanatory variables, calculated at a three-digit level of the ISIC classification. In the tradition of industrial dynamics modelling, these variables capture the different entry costs by industrial sector. Lastly, sectoral sales growth is included as a proxy variable for capturing potential demand shocks, likewise at the three-digit level of the ISIC classification. The Probit model is estimated using the maximum likelihood method.

\section{Profitability}

The profitability analysis is performed on the basis of the following empirical equation:

$$
\text { Ebitda }_{\mathrm{ijt}}=\alpha+\beta \mathrm{X}_{\mathrm{it}}+\gamma \mathrm{Z}_{\mathrm{jt}}+\mathrm{d}_{\mathrm{j}}+\mathrm{d}_{\mathrm{t}}+\varepsilon_{\mathrm{ijt}}
$$

where Ebitda $_{\mathrm{ijt}}=$ EBITDA $_{\mathrm{ijt}}-$ EBITDA $_{\mathrm{jt}}$, and EBITDA $_{\mathrm{it}}$ is earnings before interest, taxes, depreciation and amortization over sales for firm $i$ operating in sector $j$ at time $t$; and EBITDA $_{\mathrm{jt}}$ is the average of this variable for firms operating in sector $j$ at time $t$. Thus, the Ebitda variable represents the deviation from the sectoral mean of each firm's profitability. There are different reasons for using this variable instead of employing the EBITDA variable directly, such as the need to eliminate different levels of profitability between industries and effects common to all firms, such as the business cycle. ${ }^{13}$

In accordance with the earlier literature, different aspects at both the firm and the sector level are used as explanatory variables in the profitability model. Thus, firm size, the investment to capital ratio, labour skills and exporter status are included as variables. A dichotomous variable is employed to test the effect of ownership, and this takes the value 1 in the event that a firm is foreign-owned. Lastly, sectoral concentration (as measured by the Herfindahl-Hirschman index) and sectoral sales growth (as a proxy for demand shocks) are taken as control variables.

\footnotetext{
13 See Cefis and Cicarelli (2005) for a more detailed discussion of this aspect.
} 
Equation (8) is estimated empirically using quantile regressions. ${ }^{14}$ In contrast to oLs, quantile regressions estimate the relationship between variables in different quantiles of the distribution of the dependent variable (Koenker, 2005). This methodology has the advantage of being more statistically robust to extreme values and in cases where errors are not normal. Thus, this methodology can be used to adjust regressions for different quantiles of the profitability

14 In the empirical model, ownership is assumed to be exogenous to profitability. Although profitability might be expected to influence the presence of foreign capital over long periods, this is unlikely over six years. Furthermore, only $2.9 \%$ of firms changed owners during the period. distribution, something that is particularly relevant in situations of high heterogeneity. In these cases, in fact, considering the conditional mean function, as happens in traditional oLs estimations, can potentially conceal significant aspects of the relationship between the dependent variable and the explanatory variables. Thus, foreign capital can be expected to have heterogeneous effects at different points of the profitability distribution. ${ }^{15}$

15 Another study using quantile regressions to analyse the profitability of firms is Love, Roper and Du (2009) for Ireland. Although the article mainly focuses on the effects of innovation on profitability, the results also show that transnationals from the United States and the United Kingdom are more profitable than local firms.

\section{Results}

\section{Productivity}

Where productivity is concerned, TFP is analysed in both levels and differences using non-parametric and parametric evidence. The non-parametric evidence is based on a test of means (of heterogeneous variances between groups of firms) and comparison of distributions using the Kolmogorov-Smirnov test (see table 2). ${ }^{16}$ The test of means shows that transnational corporations are more profitable than domestic firms, and the difference is statistically significant. This finding is consistent whether the criterion taken is any degree of foreign ownership or over $50 \%$ foreign ownership. Accordingly, the Kolmogorov-Smirnov test suggests that the productivity levels of the two groups of firms derive from different sample distributions. In this way, an initial characterization of TFP across firms indicates that foreign ownership is a relevant factor.

The statistical analysis also reveals that there are no significant differences in terms of TFP growth. Consequently, it is not possible to reject the hypothesis that the average TFP growth rate differs between the two groups of firms. Furthermore, the average annual productivity growth rate is higher for domestic firms $(1.6 \%)$ than for transnational ones $(0.7 \%)$. This reveals that, while transnationals have higher productivity,

\footnotetext{
16 Figure A.1 presents the histogram of TFP by type of firm.
}

productivity is faster-growing in local firms. Nonetheless, it is important to control for other variables to show that these characteristics are maintained when both firm-level and sector-level variables are considered as well.

Table 3 shows the regressions of the productivity equations in levels and differences using oLs. ${ }^{17}$ Columns (1) and (2) present estimates of the TFP level. Since column (2) controls for sector-level effects (which could potentially be relevant to the way transnational corporations are distributed in industry), it is the preferred empirical model. The estimation reveals that firm size is positively associated with productivity, illustrating the benefits of economies of scale. Likewise, fixed capital investments are also associated positively with productivity. Skills present a negative and significant coefficient, which a priori is counter-intuitive. Consistently with international evidence (Wagner, 2007) and evidence for Chile (Álvarez and López, 2005), the fact of a firm exporting also correlates significantly with productivity.

The focus of interest, however, is on the variable that controls for foreign capital. The table 3 estimates suggest that transnational corporations do indeed have

\footnotetext{
17 The productivity equations could also be estimated using quantile regressions, much like the profitability equations. When they are implemented empirically, however, the results of the quantile estimations show no differences from the oLs estimations. In other words, the estimates in the different quantiles of the productivity distribution are no different from when estimation is carried out using oLs.
} 
TABLE 2

Chile: test for total factor productivity (TFP) across firms

\begin{tabular}{|c|c|c|}
\hline Variable & $\begin{array}{l}\text { Kolmogorov-Smirnov test } \\
\mathrm{H}_{0} \text { : observations are from the } \\
\text { same distribution }\end{array}$ & $\begin{array}{c}\text { Test of means } \\
\mathrm{H}_{0}: \mathrm{TFP}_{\text {transnational }}=\mathrm{TFP}_{\text {local }} \\
\mathrm{H}_{1}: \mathrm{TFP}_{\text {transnational }}>\mathrm{TFP}_{\text {local }}\end{array}$ \\
\hline \multicolumn{3}{|c|}{$\begin{array}{l}\text { I. Firms with some degree of foreign ownership compared } \\
\text { to domestic firms }\end{array}$} \\
\hline Total factor productivity (TFP) & $\begin{array}{l}0.380 \\
(0.000)^{* * * *}\end{array}$ & $\begin{array}{l}28.83 \\
(0.000)^{* * * *}\end{array}$ \\
\hline$\Delta$ Total factor productivity (TFP) & $\begin{array}{l}0.048 \\
(0.006)^{* * *}\end{array}$ & $\begin{array}{l}-0.405 \\
(0.657)\end{array}$ \\
\hline \multicolumn{3}{|c|}{$\begin{array}{l}\text { II. Firms that are at least } 50 \% \text { foreign-owned compared } \\
\text { to domestic firms }\end{array}$} \\
\hline Total factor productivity (TFP) & $\begin{array}{l}0.371 \\
(0.000)^{* * * *}\end{array}$ & $\begin{array}{l}24.66 \\
(0.000)^{* * * *}\end{array}$ \\
\hline$\Delta$ Total factor productivity (TFP) & $\begin{array}{c}0.036 \\
(0.142)\end{array}$ & $\begin{array}{c}0.071 \\
(0.523)\end{array}$ \\
\hline
\end{tabular}

Source: prepared by the author on the basis of the Annual National Industry Survey (ENIA), 2001-2006.

$* *$ Significant at $5 \%$. *** Significant at $1 \%$.

TABLE 3

Chile: total factor productivity (TFP) estimations

\begin{tabular}{|c|c|c|c|c|}
\hline Variable & $\begin{array}{l}\text { Levels } \\
\text { (1) }\end{array}$ & $\begin{array}{l}\text { Levels } \\
\text { (2) }\end{array}$ & $\begin{array}{c}\text { Differences } \\
\text { (3) }\end{array}$ & $\begin{array}{c}\text { Differences } \\
\text { (4) }\end{array}$ \\
\hline \multirow[t]{2}{*}{ Size } & 0.249 & 0.268 & -0.010 & -0.012 \\
\hline & $(25.62) * * *$ & $(33.16)^{* * *}$ & $(-2.09)^{* *}$ & $(-2.52)^{* *}$ \\
\hline \multirow[t]{2}{*}{ Investment } & 0.130 & 0.165 & 0.055 & 0.067 \\
\hline & $(4.44)^{* * *}$ & $(5.87)^{* * *}$ & $(1.65)^{*}$ & $(2.08)^{* *}$ \\
\hline \multirow[t]{2}{*}{ Skills } & -0.033 & -0.039 & -0.032 & -0.031 \\
\hline & $(1.58)$ & $(-1.99) * *$ & $(-2.54)^{* *}$ & $(-1.95)^{*}$ \\
\hline \multirow[t]{2}{*}{ Exports } & 0.208 & 0.184 & -0.001 & 0.001 \\
\hline & $(10.28)^{* * *}$ & $(10.10)^{* * *}$ & $(-0.14)$ & $(0.14)$ \\
\hline \multirow[t]{2}{*}{ Transnational } & 0.382 & 0.316 & 0.010 & 0.031 \\
\hline & $(9.36)^{* * * *}$ & $(8.94)^{* * *}$ & $(0.48)$ & $(1.36)$ \\
\hline Sector-specific effects & No & Yes & No & Yes \\
\hline Year-specific effects & No & Yes & No & Yes \\
\hline Wald chi ${ }^{2}$ test & 1190.1 & 10802.3 & 12.8 & 150.4 \\
\hline Prob. Wald $>$ chi $^{2}$ & 0.000 & 0.000 & 0.03 & 0.000 \\
\hline No. of firms & 7103 & 7103 & 6125 & 6125 \\
\hline No. of observations & 27869 & 27869 & 20589 & 20589 \\
\hline
\end{tabular}

Source: prepared by the author on the basis of the Annual National Industry Survey (ENIA), 2001-2006.

Note: the dependent variable is calculated by the methodology of Levinsohn and Petrin (2003). Explanatory variables: Size: logarithm of number of employees. Productivity: TFP calculated by the methodology of Levinsohn and Petrin (2003). Investment: ratio between physical capital investments and capital stock. Skills: ratio between numbers of skilled and unskilled employees. Exports: dichotomous variable taking the value 1 if the firm exports and 0 otherwise. Transnational: dichotomous variable taking the value 1 if the firm is foreign-owned and 0 otherwise (any percentage of foreign ownership for columns (1) to (3), over $50 \%$ for column (4)).

* Significant at $10 \%$. ** Significant at 5\%.*** Significant at $1 \%$. 
higher levels of productivity, even controlling for other firm-level and sector-level variables, which confirms the descriptive evidence. In turn, the model in column (4) uses the TFP growth rate. The results show that smaller enterprises are the ones with the highest TFP growth. Again, fixed capital investment is positively linked to productivity growth. This could be because investments in machinery and equipment can raise output and simultaneously bring other improvements, including in other areas such as organization. Consistently with the descriptive evidence, the coefficient related to the transnational variable is not significant. Thus, controlling for other variables, there are no significant differences in productivity growth rates between domestic and transnational firms.

The fact that productivity is higher in transnational corporations but productivity growth is similar across firms suggests that local firms can benefit from productivity spillovers, technology transfers and learning of new practices (Álvarez and Crespi, 2007). Thus, these findings implicitly highlight the potential impact of policies to promote technological spillover effects and the scope that exists for transnational corporations to carry out technological upgrading of their activities.

\section{Survival}

The results of the Probit model can be seen in table 4 . The base estimation model is presented in column (1), and then other control variables are added sequentially in the estimates. Size is positively associated with firms' likelihood of survival and with productivity and physical capital investment. Larger and more productive firms and those with higher investment rates have a greater likelihood of survival. These findings are consistent with other studies of firm survival for both developed and developing countries, and also for the particular case of Chile (Audretsch and Mahmood, 1995; Van Biesebroeck, 2005; Álvarez and Vergara, 2013).

Nonetheless, the main interest lies in comparing behaviour across company ownership types. According to the estimates, there are no significant differences between transnational and local firms, with the coefficients estimated in columns (2) and (3) being non-significant. As a way of testing the robustness of the estimates, however, table 4 presents similar estimates in columns (4), (5) and (6), but with the criterion of firms being at least $50 \%$ foreign-owned. The use of this criterion is justified because many administrative and strategic management decisions, such as the decision to remain in a market, to change the production mix or to issue new debt, depend on whether there is $50 \%$ ownership or not. Accordingly, it is possible that only firms that are at least $50 \%$ foreign-owned are run and behave like transnational corporations.

Consistently with the results of the previous columns, the estimates in columns (4), (5) and (6) of table 4 confirm the findings for the size, TFP and capital investment variables. However, the coefficient associated with the foreign capital variable is positive, albeit significant only at $10 \%$, showing that firms which are at least $50 \%$ foreign-owned have, on average and ceteris paribus, a $2 \%$ greater likelihood of exiting the market than local companies. Even though the effect is modest in scale and only significant at $10 \%$, it suggests that transnational corporations behave in a somewhat footloose way compared to local firms.

Taking advantage of the non-linearity of the Probit model, an analysis is conducted to determine what type of firms' survival is most affected by foreign ownership. ${ }^{18}$ Table 5 illustrates the marginal effect of foreign capital by productivity level and firm size. The effect of foreign ownership on companies that are at least $50 \%$ foreignowned is greater for small firms. The marginal effect of foreign ownership by productivity level, meanwhile, is significant only in low- and medium-productivity firms, not high-productivity ones, which are probably exporters.

The last thing to be tested is whether the characteristics of the sectors where transnational corporations operate are relevant to their likelihood of survival. First, the estimates show that all businesses operating in knowledgeintensive sectors seem to have lower survival rates than firms in other sectors (see columns (1) and (3) of table A.2). However, this loses significance when sectoral effects at the three-digit level of ISIC are added in, so that it is not possible to draw consistent conclusions (see columns (2) and (4) of table A.2). As to whether transnational corporations behave differently depending on the sector they operate in, the estimates show this not to be the case (see table A.3). In fact, the marginal effect estimated for transnational corporations (using the two criteria of there being some degree of foreign ownership and more than $50 \%$ foreign ownership) is similar across sectors and confirms the results of the previous estimates: only transnational corporations that are over 50\% foreign-owned are less likely to survive (at 10\% significance), and this finding is homogeneous

\footnotetext{
18 In a Probit model, marginal effects are a function of the other explanatory variables. Marginal effects are usually calculated using the average value for these variables. The marginal effect corresponds to the expression: $\partial \operatorname{Pr}(y=1) / \partial X_{k}=\phi\left(X^{\prime} \beta\right) \beta_{k}$.
} 
TABLE 4

Chile: firm survival, Probit models (marginal effects)

\begin{tabular}{|c|c|c|c|c|c|c|}
\hline Variable & (1) & $(2)$ & (3) & (4) & (5) & (6) \\
\hline Size & $\begin{array}{l}0.018 \\
(8.48)^{* * *}\end{array}$ & $\begin{array}{l}0.019 \\
(8.10)^{* * *}\end{array}$ & $\begin{array}{l}0.019 \\
(8.08)^{* * * *}\end{array}$ & $\begin{array}{l}0.018 \\
(8.48)^{* * *}\end{array}$ & $\begin{array}{l}0.019 \\
(8.09)^{* * * *}\end{array}$ & $\begin{array}{l}0.019 \\
(8.07)^{* * *}\end{array}$ \\
\hline Productivity & $\begin{array}{l}0.015 \\
(6.89)^{* * *}\end{array}$ & $\begin{array}{l}0.016 \\
(7.06)^{* * *}\end{array}$ & $\begin{array}{l}0.016 \\
(7.04)^{* * *}\end{array}$ & $\begin{array}{l}0.015 \\
(6.89)^{* * * *}\end{array}$ & $\begin{array}{l}0.016 \\
(7.09) * * *\end{array}$ & $\begin{array}{l}0.015 \\
(7.08)^{* * *}\end{array}$ \\
\hline Investment & $\begin{array}{l}0.039 \\
(3.14)^{* *}\end{array}$ & $\begin{array}{l}0.039 \\
(3.13)^{* *}\end{array}$ & $\begin{array}{l}0.039 \\
(3.13)^{* *}\end{array}$ & $\begin{array}{l}0.039 \\
(3.14)^{* *}\end{array}$ & $\begin{array}{c}0.038 \\
(3.13)^{* *}\end{array}$ & $\begin{array}{l}0.039 \\
(3.14)^{* *}\end{array}$ \\
\hline Skills & $\begin{array}{l}-0.005 \\
(-0.80)\end{array}$ & $\begin{array}{l}-0.004 \\
(-0.70)\end{array}$ & $\begin{array}{l}-0.004 \\
(-0.68)\end{array}$ & $\begin{array}{l}-0.005 \\
(-0.80)\end{array}$ & $\begin{array}{l}-0.004 \\
(-0.68)\end{array}$ & $\begin{array}{l}-0.004 \\
(-0.67)\end{array}$ \\
\hline Exports & $\begin{array}{c}-0.003 \\
(-0.54)\end{array}$ & $\begin{array}{c}-0.004 \\
(-0.55)\end{array}$ & $\begin{array}{c}-0.003 \\
(-0.55)\end{array}$ & $\begin{array}{c}-0.003 \\
(-0.48)\end{array}$ & $\begin{array}{c}-0.002 \\
(-0.48)\end{array}$ & $\begin{array}{c}-0.003 \\
(-0.49)\end{array}$ \\
\hline Transnational & & $\begin{array}{l}-0.013 \\
(-1.41)\end{array}$ & $\begin{array}{c}-0.013 \\
(-1.42)\end{array}$ & & $\begin{array}{c}-0.019 \\
(-1.83)^{*}\end{array}$ & $\begin{array}{l}-0.019 \\
(-1.83)^{*}\end{array}$ \\
\hline Concentration & & & $\begin{array}{c}0.098 \\
(1.06)\end{array}$ & & & $\begin{array}{c}0.096 \\
(1.04)\end{array}$ \\
\hline Average firm size & & & $\begin{array}{c}0.029 \\
(0.75)\end{array}$ & & & $\begin{array}{c}0.029 \\
(0.75)\end{array}$ \\
\hline Sectoral growth & & & $\begin{array}{c}0.11 \\
(0.88)\end{array}$ & & & $\begin{array}{c}0.122 \\
(0.91)\end{array}$ \\
\hline Sector-specific effects & Yes & Yes & Yes & Yes & Yes & Yes \\
\hline Year-specific effects & Yes & Yes & Yes & Yes & Yes & Yes \\
\hline Wald Chi test (36) & 470.7 & 473.6 & 474.3 & 470.7 & 473.8 & 474.3 \\
\hline Prob. Wald $>\mathrm{Chi}^{2}$ & 0.000 & 0.000 & 0.000 & 0.000 & 0.000 & 0.000 \\
\hline No. of observations & 23322 & 23322 & 23322 & 23322 & 23222 & 23222 \\
\hline
\end{tabular}

Source: prepared by the author on the basis of the Annual National Industry Survey (ENIA), 2001-2006.

Note: the dependent variable is equal to 1 if the firm has operations at $t+1$ and 0 otherwise. Size: logarithm of number of employees. Productivity: calculated by the methodology of Levinsohn and Petrin (2003). Investments: ratio between physical capital investments and capital stock. Skills: ratio between numbers of skilled and unskilled employees. Exports: dichotomous variable taking the value 1 if the firm exports and 0 otherwise. Transnational: dichotomous variable taking the value 1 if the firm is foreign-owned and 0 otherwise (any percentage of foreign ownership for columns (1) to (3), over $50 \%$ for columns (4) to (6)). Concentration: Herfindahl-Hirschman index calculated from gross output value by sector (three-digit ISIC) and year. Average firm size: average number of employees by sector (three-digit ISIC) and year. Sectoral growth: change in gross output value by sector (three-digit ISIC) and year. All estimates include sector- and year-specific effects.

* Significant at $10 \%$. ** Significant at $5 \%$. *** Significant at $1 \%$.

across sectors. This shows that transnational corporations in knowledge-intensive sectors do not behave any differently in terms of survival.

In summary, small, low-productivity firms with majority foreign ownership evince a greater likelihood of exit than their local counterparts, irrespective of the sectors they operate in. This could be because these firms tend to suffer more acutely from the fluctuations of the local business cycle owing to unfamiliarity with the market, lack of linkages and lesser flexibility when it comes to adjusting to conditions of lower demand. This finding is consistent with what was presented by Álvarez and Görg (2009) for manufacturing industry in Chile, but during the 1990s. The authors show that transnational corporations geared to the domestic market are the least likely to survive.
TABLE 5

Chile: marginal effects of foreign ownership on firm survival a

\begin{tabular}{ccc}
\hline \multicolumn{3}{c}{ By firm size } \\
\hline Small & Medium & Large \\
\hline-0.022 & -0.012 & -0.008 \\
$(-1.69)^{*}$ & $(-1.66)^{*}$ & $(-1.62)^{*}$ \\
\hline \multicolumn{3}{|c}{ By firm productivity } \\
\hline Low & Medium & High \\
\hline-0.033 & -0.014 & -0.004 \\
$(-1.79)^{*}$ & $(-1.67)^{*}$ & $(-1.50)$ \\
\hline
\end{tabular}

Source: prepared by the author on the basis of the Annual National Industry Survey (ENIA), 2001-2006.

${ }^{\text {a }}$ Marginal effects calculated from the results of column (6) in table 4.

* Significant at $10 \%$. 


\section{Profitability}

The profitability estimations arrived at by using quantile regressions are presented in tables 6 and $7 .^{19}$ These estimates are justified in this case because the profitability and residuals estimated from equation (8) using oLs do not have a normal distribution. ${ }^{20}$ Tables 6 and 7 differ only in the criterion used to define a transnational: some degree of foreign ownership in the first case and at least $50 \%$ in the second. The oLs estimates are also presented for the purposes of comparison.

The estimates present some consistent results, mainly the positive correlation between profitability and the variables that control for size and capital

19 Figure A.2 presents the histogram of profitability by firm type.

20 The test rejects the normal distribution both for profitability and for the residuals estimated from equation (8) with a $1 \%$ significance level. investment. Indeed, there is ample evidence that size is a significant determinant of profitability, since it tends to be associated with benefits arising from economies of scale and better borrowing conditions. The positive correlation with investment may be reflecting a good short-term business outlook. In a number of quantiles, furthermore, it can be seen that exporting firms have higher profitability, which could reflect both greater capabilities within the company and less vulnerability to swings in local demand.

The central goal of this subsection is to analyse the correlation with the variable that controls for a firm being transnational. A preliminary observation is that there is a positive relationship between profitability and foreign ownership in the oLs estimates. However, it is evident that estimating by oLs does not do a good job of calculating an average effect for the sample. In fact, the quantile estimates provide greater information by

TABLE 6

Quantile regressions of profitability (1)

\begin{tabular}{|c|c|c|c|c|c|c|}
\hline \multirow{2}{*}{ Variable } & \multirow{2}{*}{ OLS } & \multicolumn{5}{|c|}{ Quantile } \\
\hline & & 0.1 & 0.25 & 0.5 & 0.75 & 0.9 \\
\hline \multirow[t]{2}{*}{ Size } & 0.009 & 0.022 & 0.014 & 0.008 & 0.004 & -0.001 \\
\hline & $(7.93)^{* * *}$ & $(12.18)^{* * *}$ & (11.80) & $(7.61)^{* * *}$ & $(3.03)^{* *}$ & $(-0.44)$ \\
\hline \multirow[t]{2}{*}{ Investment } & 0.023 & 0.017 & 0.033 & 0.026 & 0.023 & 0.003 \\
\hline & $(3.47)^{* *}$ & $(1.68)^{*}$ & $(4.72)^{* * *}$ & $(4.11)^{* * *}$ & $(2.91)^{* *}$ & $(0.29)$ \\
\hline \multirow[t]{2}{*}{ Skills } & 0.010 & 0.000 & 0.002 & 0.006 & 0.014 & 0.023 \\
\hline & $(2.90)^{* *}$ & $(0.03)$ & $(0.75)$ & $(1.78)^{*}$ & $(3.04)^{* *}$ & $(3.62)^{* * *}$ \\
\hline \multirow[t]{2}{*}{ Exports } & 0.009 & -0.011 & 0.004 & 0.008 & 0.020 & 0.035 \\
\hline & $(2.76)^{* *}$ & $(-2.28)^{* *}$ & $(-1.43)$ & $(2.58)^{*}$ & $(4.80)^{* * *}$ & $(6.05)^{* * *}$ \\
\hline \multirow[t]{2}{*}{ Transnational 1} & 0.011 & -0.030 & -0.015 & -0.001 & 0.029 & 0.058 \\
\hline & $(2.10)^{* *}$ & $(-4.14)^{* * *}$ & $(-2.95)^{* *}$ & $(-0.25)$ & $(4.88)^{* * *}$ & $(6.91)^{* * *}$ \\
\hline \multirow[t]{2}{*}{ Concentration } & 0.060 & -0.036 & 0.016 & 0.036 & 0.047 & 0.144 \\
\hline & (1.17) & $(-0.50)$ & $(0.33)$ & $(0.74)$ & $(0.78)$ & $(1.71)^{*}$ \\
\hline \multirow[t]{2}{*}{ Sectoral growth } & 0.013 & 0.094 & -0.011 & 0.007 & 0.025 & 0.039 \\
\hline & $(1.42)$ & $(6.23)^{* * *}$ & $(-1.26)$ & $(0.71)$ & $(2.58)^{*}$ & $(3.29)^{* *}$ \\
\hline Sector-specific effects & Yes & Yes & Yes & Yes & Yes & Yes \\
\hline Year-specific effects & Yes & Yes & Yes & Yes & Yes & Yes \\
\hline No. of observations & 28895 & 28895 & 28895 & 28895 & 28895 & 28895 \\
\hline
\end{tabular}

Source: prepared by the author on the basis of the Annual National Industry Survey (ENIA), 2001-2006.

Note: dependent variable: $E b i t d a_{i j t}=$ EBITDA $_{i j t}-$ EBITDA $_{j t}$, where EBITDA $i t$ represents earnings before interest, taxes, depreciation and amortization over sales for firm $i$ operating in sector $j$ at time $t$, and EBITDA $_{j t}$ is the average of this variable for firms operating in sector $j$ at time $t$. Size: logarithm of number of employees. Investment: ratio between physical capital investments and capital stock. Skills: ratio between numbers of skilled and unskilled employees. Exports: dichotomous variable taking the value 1 if the firm exports and 0 otherwise. Transnational 1: dichotomous variable taking the value 1 if the firm has some degree of foreign ownership and 0 otherwise. Concentration: HerfindahlHirschman index calculated from gross output value by sector (three-digit ISIC) and year. Sectoral growth: change in gross output value by sector (three-digit ISIC) and year. OLS: ordinary least squares.

* Significant at 10\%. ** Significant at 5\%.*** Significant at $1 \%$. 
TABLE 7

Quantile regressions of profitability (2)

\begin{tabular}{|c|c|c|c|c|c|c|}
\hline \multirow{2}{*}{ Variable } & \multirow{2}{*}{ OLS } & \multicolumn{5}{|c|}{ Quantile } \\
\hline & & 0.1 & 0.25 & 0.5 & 0.75 & 0.9 \\
\hline \multirow[t]{2}{*}{ Size } & 0.011 & 0.021 & 0.014 & 0.008 & 0.004 & -0.000 \\
\hline & $(10.27)^{* * *}$ & $(11.33)^{* * *}$ & $(11.49) * * *$ & $(7.62)^{* * * *}$ & $(3.24)^{* *}$ & $(-0.04)$ \\
\hline \multirow[t]{2}{*}{ Investment } & 0.023 & 0.015 & 0.032 & 0.026 & 0.024 & 0.001 \\
\hline & $(3.44)^{* *}$ & $(1.37)$ & $(4.57)^{* * *}$ & $(4.13)^{* * *}$ & $(3.07)^{* *}$ & $(0.17)$ \\
\hline \multirow[t]{2}{*}{ Skills } & 0.011 & 0.000 & 0.002 & 0.006 & 0.014 & 0.023 \\
\hline & $(3.11)^{* *}$ & $(0.06)$ & $(0.53)$ & $(1.92)^{*}$ & $(3.14)^{* *}$ & $(3.67)^{* * *}$ \\
\hline \multirow[t]{2}{*}{ Exports } & 0.010 & -0.010 & -0.005 & 0.009 & 0.023 & 0.039 \\
\hline & $(3.15)^{* *}$ & $(-2.07) * *$ & $(-1.60)$ & $(3.01)^{* *}$ & $(5.64)^{* * *}$ & $(6.94)^{* * *}$ \\
\hline \multirow[t]{2}{*}{ Transnational 2} & 0.000 & -0.026 & -0.013 & -0.007 & 0.010 & 0.023 \\
\hline & $(0.04)$ & $(-3.11) * *$ & $(-2.35)^{* *}$ & $(-1.50)$ & $(1.58)$ & $(2.46)^{* *}$ \\
\hline \multirow[t]{2}{*}{ Concentration } & 0.060 & -0.060 & 0.018 & 0.026 & 0.025 & 0.152 \\
\hline & $(1.17)$ & $(-0.79)$ & $(0.35)$ & $(0.55)$ & $(2.53)^{* *}$ & $(1.82)^{*}$ \\
\hline \multirow[t]{2}{*}{ Sectoral growth } & 0.015 & 0.099 & -0.011 & 0.006 & 0.074 & 0.040 \\
\hline & $(1.62)^{*}$ & $(6.27)^{* * *}$ & $(-1.23)$ & $(0.65)$ & $(5.71)^{* * *}$ & $(3.47)^{* *}$ \\
\hline Sector-specific effects & Yes & Yes & Yes & Yes & Yes & Yes \\
\hline Year-specific effects & Yes & Yes & Yes & Yes & Yes & Yes \\
\hline No. of observations & 28895 & 28895 & 28895 & 28895 & 28895 & 28895 \\
\hline
\end{tabular}

Source: prepared by the author on the basis of the Annual National Industry Survey (ENIA), 2001-2006.

Note: dependent variable: Ebitd $_{i j t}=\mathrm{EBITDA}_{i j t}-\mathrm{EBITDA}_{j t}$, where EBITDA $i t$ represents earnings before interest, taxes, depreciation and amortization over sales for firm $i$ operating in sector $j$ at time $t$, and EBITDA $j t$ is the average of this variable for firms operating in sector $j$ at time $t$. Size: logarithm of number of employees. Investment: ratio between physical capital investments and capital stock. Skills: ratio between number of skilled and unskilled employees. Exports: dichotomous variable taking the value 1 if the firm exports and 0 otherwise. Transnational 2: dichotomous variable taking the value 1 if the firm is over $50 \%$ foreign-owned and 0 otherwise. Concentration: Herfindahl-Hirschman index calculated from gross output value by sector (three-digit ISIC) and year. Sectoral growth: change in gross output value by sector (three-digit ISIC) and year. OLS: ordinary least squares.

* Significant at $10 \%$. ** Significant at 5\%.*** Significant at $1 \%$.

showing a heterogeneous effect at the different points of the profitability distribution. In both estimates, i.e., using both criteria for defining a transnational firm, the coefficient is negative and significant in the first two quantiles of the profitability distribution. This suggests that in situations of relatively low corporate profitability, foreign ownership seems to correlate negatively with firm performance. Thus, transnational corporations are less profitable than local firms. This could be explained by the fact that transnational corporations with low profitability might suffer more acutely than local firms in the same sector from unfamiliarity with the market, lack of productive linkages and lack of flexibility and strategic management when adapting to more competitive conditions and changes in demand patterns. For example, transnational corporations may have determined their product mix by criteria that are not exclusively local. This finding is consistent with what was presented in the previous section, where it was noted that small and less productive transnational corporations were more likely to exit the market. Thus, one important point that could explain this result would be that these transnational corporations are less profitable than local firms.

Similarly, the estimates show that foreign ownership is linked positively and significantly to profitability in the two quantiles above the mean of the profitability distribution. Thus, in situations of relatively high profits, transnational corporations perform better than local companies and can exploit advantages associated with economies of scale, patents, licences and specific technologies, distribution 
channels abroad or financing conditions. Strictly speaking, it is not possible to speak of firms with high or low profitability in cases where a quantile regression is implemented on panel data. However, since the standard deviation of intra-firm profitability is half the deviation between firms, it can be broadly assumed that the observations in the high-profitability quintiles are associated with high-profitability firms, while the observations in the low quintiles concern

\section{VI}

\section{Conclusions}

This article analyses the performance of transnational corporations in manufacturing industry in the context of a small open economy like Chile's. First, the results show that subsidiaries of transnational corporations behave differently from domestic firms, and also from one another when their characteristics differ, which highlights the high level of heterogeneity in manufacturing industry. Second, productivity is higher in transnational corporations than in local firms, but not faster-growing. Third, the results suggest that local and transnational firms do not greatly differ in terms of market survival. However, a more detailed analysis also shows that firms which are mainly foreign-owned, and especially small ones with low productivity, are more likely to exit the market than their local counterparts. This is associated with lower profitability in the first distribution quantiles. Low-productivity subsidiaries of transnational companies probably have little market knowledge, fewer linkages and less ability to adjust to swings in domestic demand. Lastly, the results show that there is no linear, unequivocal link between foreign ownership and profitability. For low-profitability firms. ${ }^{21}$ Thus, it could be argued that among high-profitability companies, transnational firms perform better than local ones. Conversely, among low-profitability companies, it is local ones that perform better.

21 Estimates from equation (8) using average variables at the firm level (for both profitability and the explanatory variables) yield similar conclusions. example, transnational corporations seem to be more profitable than local firms only in the upper quantiles of the profitability distribution. In other words, it cannot be assumed that the subsidiaries of transnationals have permanently and robustly higher rates of profit than local firms.

In summary, this article discusses some of the peculiarities characterizing the operations of transnational corporations in the highly heterogeneous context of the Chilean manufacturing sector. These results obviously cannot be extended to other production sectors, such as natural resources or services, where patterns of competition and the characteristics of the subsidiaries of transnational corporations are significantly different from those in the manufacturing sector. It is important to consider these performance patterns of transnational corporations at a time like the present, when foreign investment flows into the region are surging, and especially when production and technology policies designed to enhance the benefits of these to host economies are under discussion. 
ANNEX

FIGURE A.1

Histogram of total factor productivity (TFP)

A. Local firms

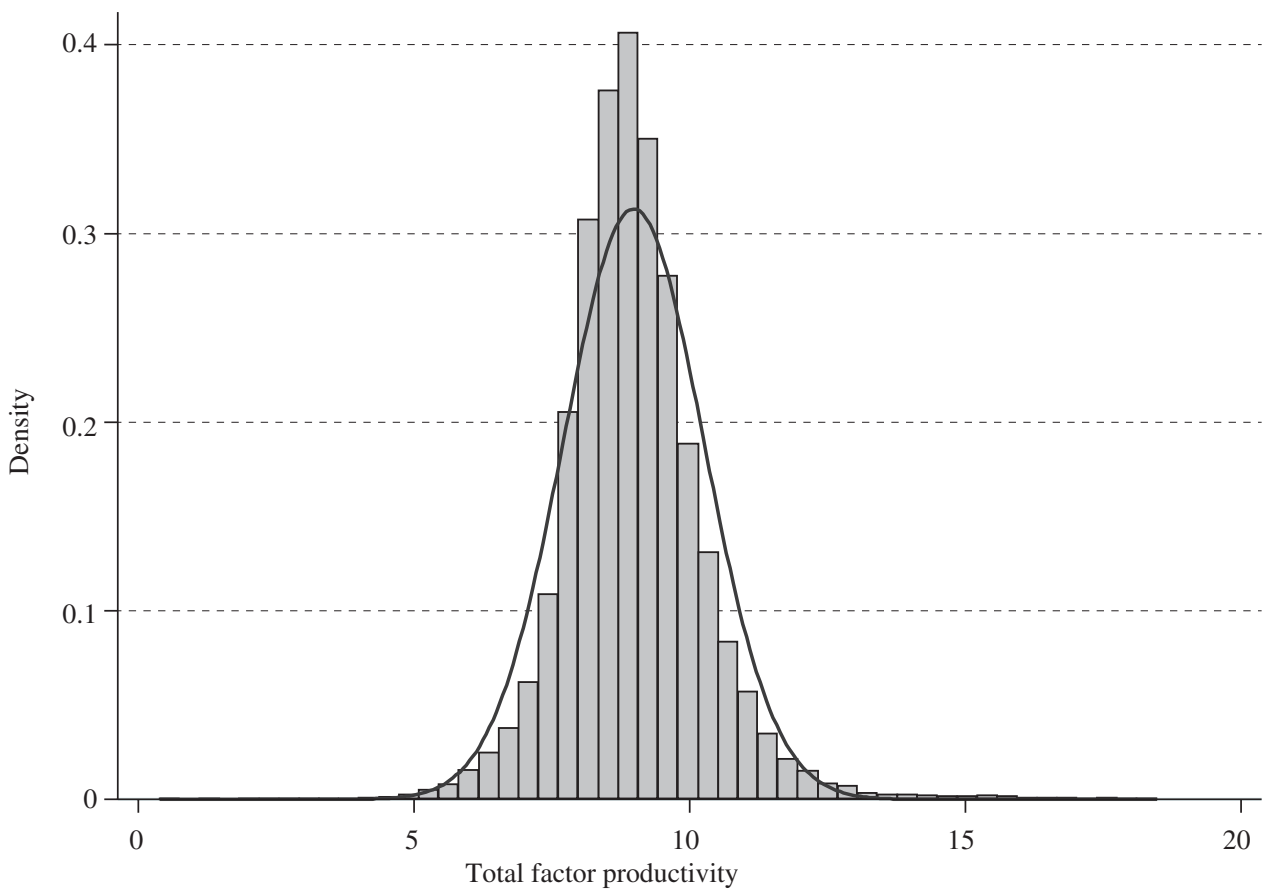

B. Transnational corporations

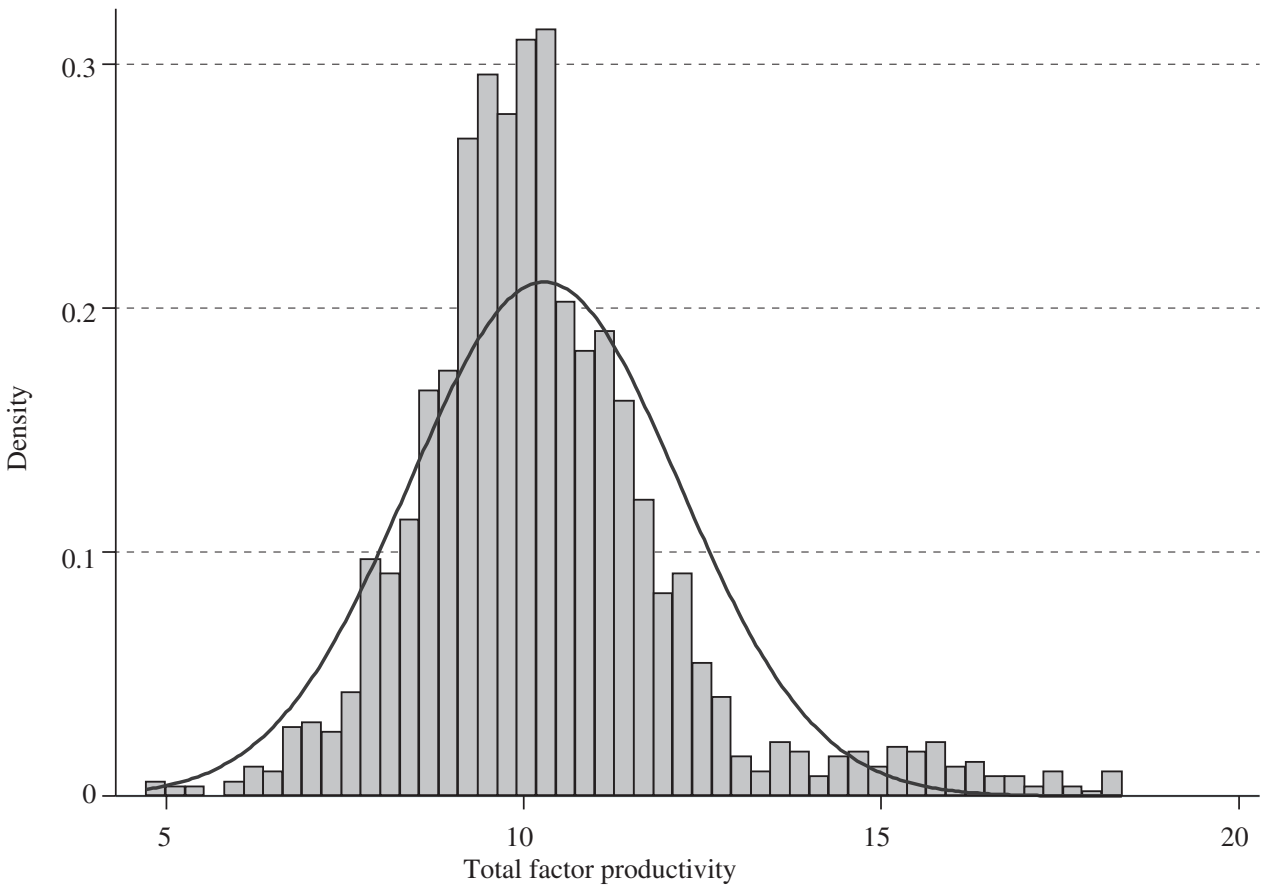

Source: prepared by the author on the basis of the Annual National Industry Survey (ENIA), 2001-2006. 
FIGURE A.2

Histogram of profitability

A. Local firms

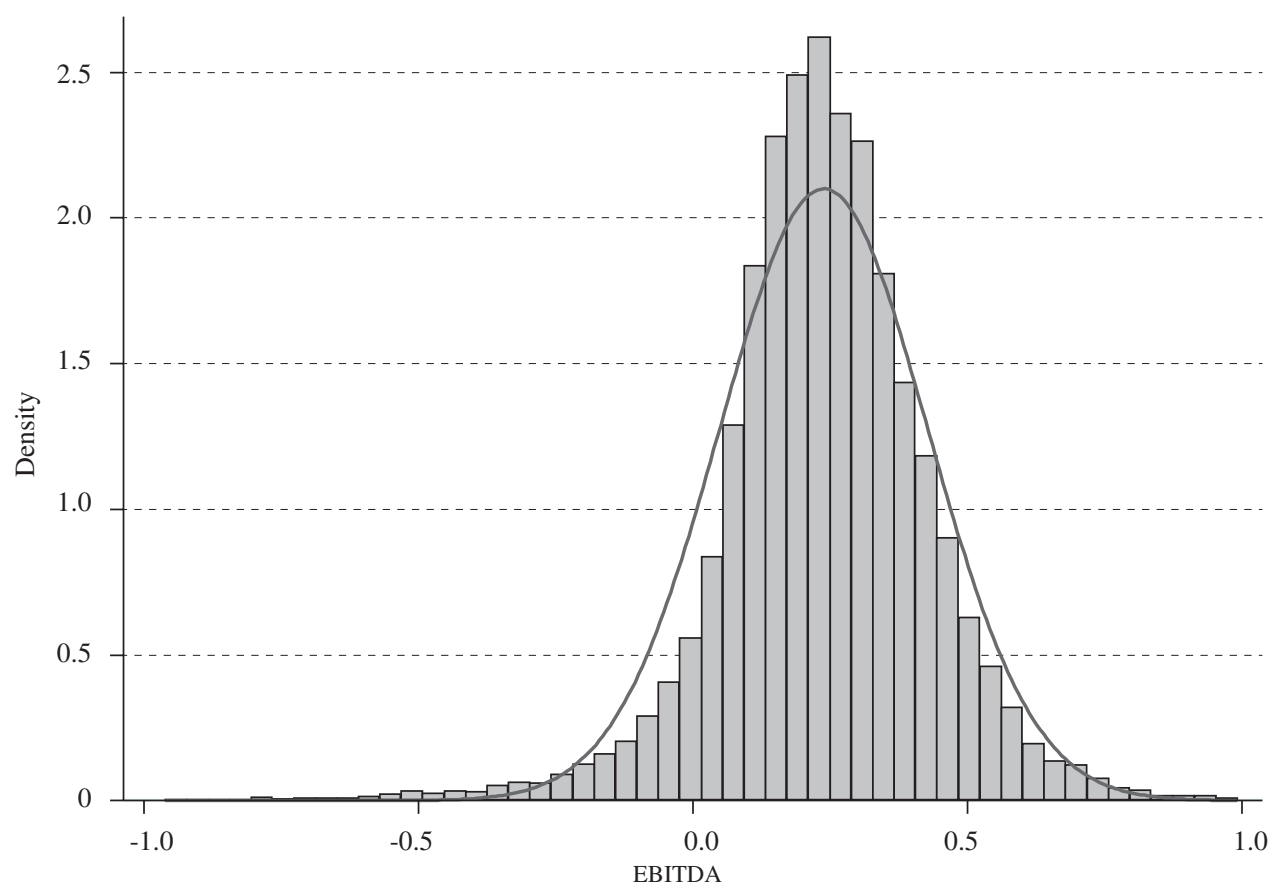

B. Transnational corporations

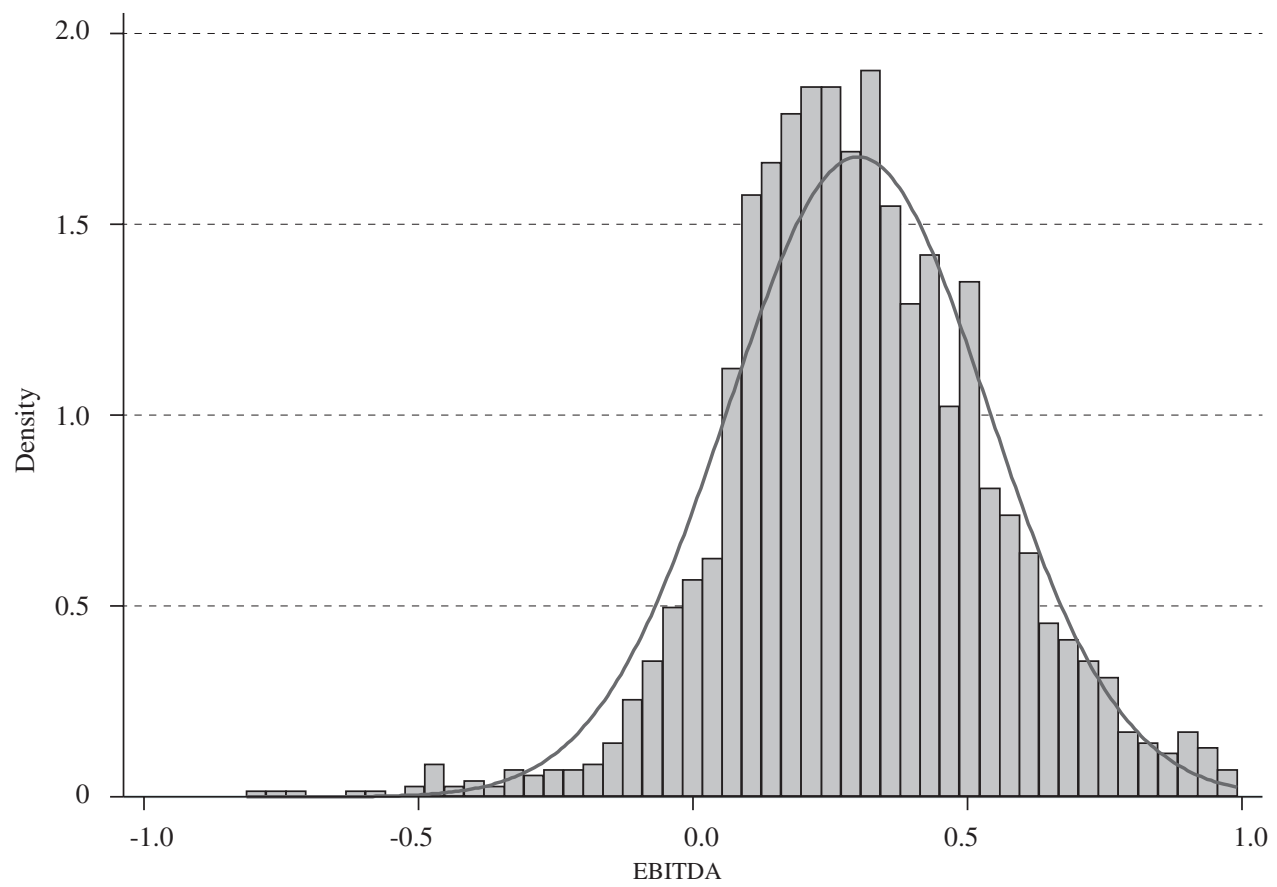

Source: prepared by the author on the basis of the Annual National Industry Survey (ENIA), 2001-2006.

EBITDA: earnings before interest, taxes, depreciation and amortization over sales. 


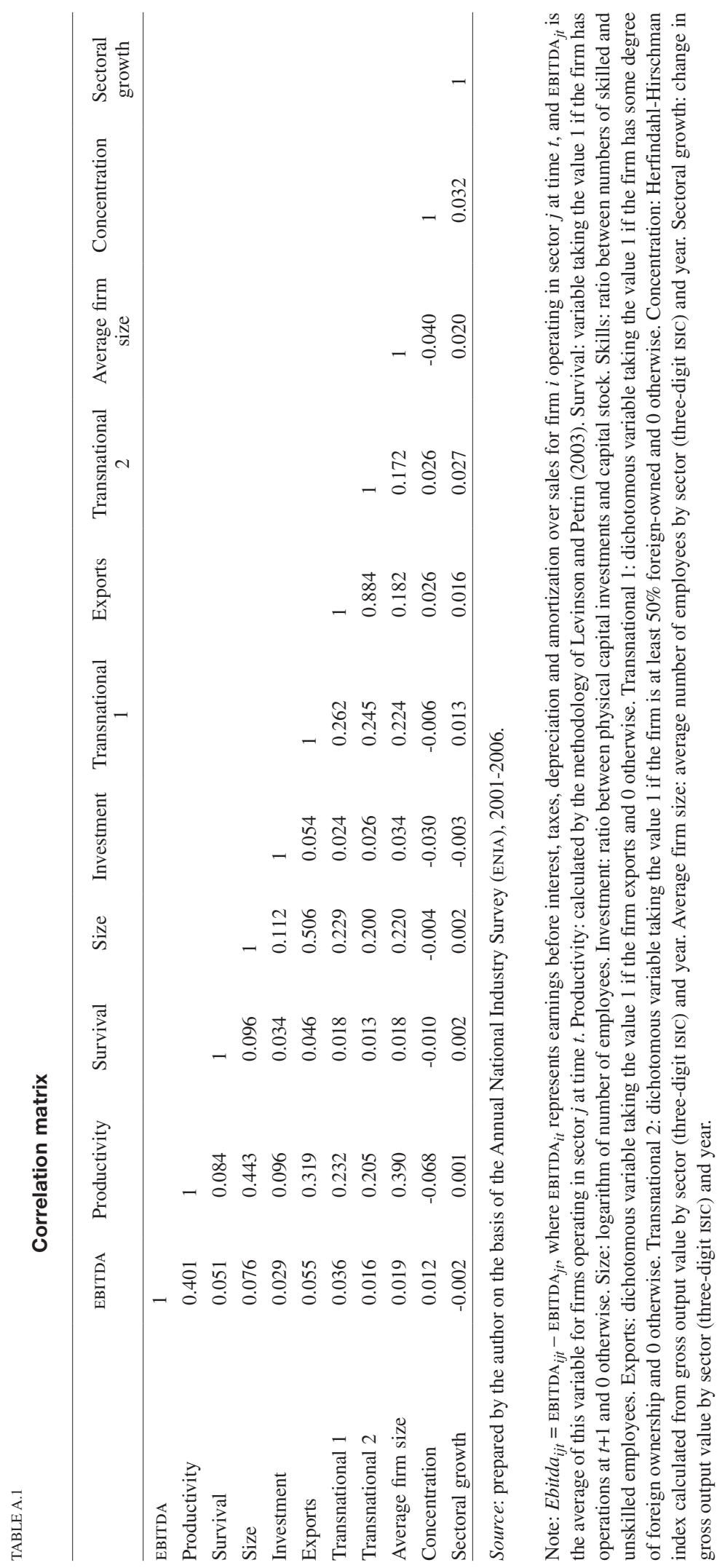


TABLE A.2

Firm survival, Probit models (marginal effects)

\begin{tabular}{|c|c|c|c|c|}
\hline Variable & (1) & (2) & (3) & (4) \\
\hline \multirow[t]{2}{*}{ Size } & 0.019 & 0.019 & 0.019 & 0.019 \\
\hline & $(8.11)^{* * *}$ & $(7.91)^{* * *}$ & $(8.10)^{* * *}$ & $(7.90)^{* * * *}$ \\
\hline \multirow[t]{2}{*}{ Productivity } & 0.015 & 0.015 & 0.015 & 0.015 \\
\hline & $(7.79)^{* * *}$ & $(6.96)^{* * *}$ & $(7.84)^{* * *}$ & $(7.00)^{* * * *}$ \\
\hline \multirow[t]{2}{*}{ Investment } & 0.040 & 0.039 & 0.040 & 0.039 \\
\hline & $(3.24)^{* * *}$ & $(3.13)^{* *}$ & $(3.24)^{* *}$ & $(3.13)^{* * *}$ \\
\hline \multirow[t]{2}{*}{ Skills } & -0.004 & -0.004 & -0.004 & -0.004 \\
\hline & $(0.67)$ & $(0.66)$ & $(0.65)$ & $(0.64)$ \\
\hline \multirow[t]{2}{*}{ Exports } & -0.002 & -0.003 & -0.002 & -0.003 \\
\hline & $(0.44)$ & $(0.65)$ & $(0.40)$ & $(0.59)$ \\
\hline \multirow[t]{2}{*}{ Transnational } & -0.009 & -0.012 & -0.014 & -0.018 \\
\hline & $(1.07)$ & $(1.33)$ & $(1.46)$ & $(1.79)^{*}$ \\
\hline Concentration & -0.008 & 0.099 & -0.008 & 0.097 \\
\hline \multirow[t]{2}{*}{ Average firm size } & -0.017 & 0.029 & -0.016 & 0.029 \\
\hline & $(1.92)^{* *}$ & $(0.75)$ & $(1.88)^{*}$ & $(0.76)$ \\
\hline \multirow[t]{2}{*}{ Sectoral growth } & 0.118 & 0.114 & 0.121 & 0.119 \\
\hline & $(0.86)$ & $(0.87)$ & $(0.88)$ & $(0.89)$ \\
\hline \multirow[t]{2}{*}{ Natural resource dummy } & 0.001 & -0.020 & 0.002 & -0.021 \\
\hline & $(0.42)$ & $(0.97)$ & $(0.46)$ & $(0.97)$ \\
\hline \multirow[t]{2}{*}{ Knowledge dummy } & -0.016 & -0.011 & -0.015 & -0.010 \\
\hline & $(2.75)^{* *}$ & $(0.39)$ & $(2.72)^{* *}$ & $0.35)$ \\
\hline Sector-specific effects & No & Yes & No & Yes \\
\hline Year-specific effects & Yes & Yes & Yes & Yes \\
\hline Wald Chi test (36) & 436.98 & 471.29 & 436.94 & 471.18 \\
\hline Prob. Wald $>\mathrm{Chi}^{2}$ & 0.000 & 0.000 & 0.000 & 0.000 \\
\hline No. of observations & 23322 & 23322 & 23322 & 23322 \\
\hline
\end{tabular}

Source: prepared by the author on the basis of the Annual National Industry Survey (ENIA), 2001-2006.

Note: the dependent variable is equal to 1 if the firm has operations at $t+1$ and 0 otherwise. Size: logarithm of number of employees. Productivity: calculated by the methodology of Levinsohn and Petrin (2003). Investment: ratio between physical capital investments and capital stock. Skills: ratio between numbers of skilled and unskilled employees. Exports: average of a dichotomous variable taking the value 1 if the firm exports and 0 otherwise. Transnational: dichotomous variable taking the value 1 if the firm is foreign-owned and 0 otherwise (any percentage of foreign ownership for columns (1) and (2), over 50\% for columns (3) and (4)). Concentration: Herfindahl-Hirschman index calculated from gross output value by sector (three-digit ISIC) and year. Average firm size: average number of employees by sector sector (three-digit ISIC) and year. Sectoral growth: change in gross output value by sector (three-digit ISIC) and year. Knowledge dummy: variable taking the value 1 if the firm operates in knowledge-intensive sectors and 0 otherwise. Natural resource dummy: variable taking the value 1 if the firm operates in natural resourceintensive sectors and 0 otherwise. All the estimates include sector- and year-specific effects.

$*$ Significant at $10 \%$.** Significant at 5\%.*** Significant at $1 \%$.

TABLE A.3

Marginal effects of foreign ownership on firm survival ${ }^{a}$

\begin{tabular}{lcc}
\hline Degree of foreign ownership & Knowledge-intensive sectors & Other sectors \\
\hline Transnational 1 & -0.012 & -0.013 \\
(some degree of foreign ownership) & $(1.27)$ & $(1.26)$ \\
Transnational 2 & -0.019 & -0.018 \\
(al least 50\% foreign ownership) & $(1.65)^{*}$ & $(1.67)^{*}$ \\
\hline
\end{tabular}

Source: prepared by the author on the basis of the Annual National Industry Survey (ENIA), 2001-2006.

a Marginal effects calculated from the results of columns (2) and (4) of table A.2.

* Significant at $10 \%$. 


\section{Bibliography}

Álvarez, R. and G. Crespi (2007), "Multinational firms and productivity catching-up: the case of Chilean manufacturing", International Journal of Technological Learning, Innovation and Development, vol. 1, No. 2, Inderscience Enterprises Ltd., January.

Álvarez, R. and H. Görg (2009), "Multinationals and plant exit: evidence from Chile", International Review of Economics and Finance, vol. 18, No. 1, Amsterdam, Elsevier.

Álvarez, R. and R. López (2008), "Is exporting a source of productivity spillovers?”, Review of World Economics, vol. 144, No. 4, Springer, December.

(2005), "Exporting and performance: evidence from Chilean plants", Canadian Journal of Economics, vol. 38, No. 4, Quebec, Canadian Economics Association.

Álvarez, R. and S. Vergara (2013), "Trade exposure, survival and growth of small and medium-size firms", International Review of Economics \& Finance, vol. 25(C), Amsterdam, Elsevier.

Audretsch, D. and T. Mahmood (1995), "New firm survival: new results using a hazard function", The Review of Economics and Statistics, vol. 77, No. 3, Cambridge, Massachusetts, The MIT Press, August.

Baldwin, R., R. Lipsey and J. Richards (1998), Geography and Ownership as Bases for Economic Accounting, Chicago, The University of Chicago Press.

Bandick, R. (2010), "Multinationals and plant survival", Review of World Economics, vol. 146, No. 4, Springer.

Barbosa, N. and H. Louri (2005), "Corporate performance: does ownership matter? A comparison of foreign- and domesticowned firms in Greece and Portugal", Review of Industrial Organization, vol. 27, No. 1, Springer.

Benvignati, A. (1987), "Domestic profit advantages of multinational firms", The Journal of Business, vol. 60, No. 3, Chicago, The University of Chicago Press, July.

Bernard, A. and F. Sjoholm (2003), "Foreign owners and plant survival", NBER Working Papers, No. 10039, Cambridge, Massachusetts, National Bureau of Economic Research.

Blomström, M. (1988), "Labor productivity differences between foreign and domestic firms in Mexico", World Development, vol. 16, No. 11, Amsterdam, Elsevier, November.

Blomström, M. and F. Sjöholm (1999), "Technology, transfer and spillovers: does local participation with multinationals matter?", European Economic Review, vol. 43, No. 4-6, Amsterdam, Elsevier.

Caves, R.E. (1996), Multinational Enterprise and Economic Analysis, Cambridge, Cambridge University Press.

Cefis, E. and M. Ciccarelli (2005), "Profit differentials and innovation", Economics of Innovation and New Technologies, vol. 14, No. 1-2, Taylor \& Francis.

Cimoli, M. and others (2005), "Cambio estructural, heterogeneidad productiva y tecnología en América Latina", Heterogeneidad estructural, asimetrías tecnológicas y crecimiento en América Latina, M. Cimoli (ed.), Santiago, Chile, Economic Commission for Latin America and the Caribbean (ECLAC)/Inter-American Development Bank (IDB).

Cohen, S.D. (2007), Multinational Corporations and Foreign Direct Investment: Avoiding Simplicity, Embracing Complexity, New York, Oxford University Press.

Crespi, G., C. Criscuolo and J. Haskel (2006), "Information technology, organizational change, and productivity growth", Working Papers, No. 558, London, Queen Mary University of London.

Dimelis, S. and H. Louri (2002), "Foreign ownership and production efficiency: a quantile regression analysis", Oxford Economic Papers, vol. 54, No. 3, Oxford, Oxford University Press.

Doms, M., T. Dunne and M. Roberts (1995), "The role of technology use in the survival and growth of manufacturing plants", International Journal of Industrial Organization, vol. 13, No. 4, Amsterdam, Elsevier, December.
Dunning, J.H. (2000) "The eclectic paradigm as an envelope for economic and business theories of MNE activity", International Business Review, vol. 9, No. 2, Amsterdam, Elsevier.

ECLAC (Economic Commission for Latin America and the Caribbean) (2012), Foreign Direct Investment in Latin America and the Caribbean, 2011 (LC/G.2538-P), Santiago, Chile, June. United Nations publication, Sales No. E.12.II.G.4.

(2011), Foreign Direct Investment in Latin America and the Caribbean, 2010 (LC/G.2494-P), Santiago, Chile, May. United Nations publication, Sales No. E.11.II.G.4.

(2006), Foreign Investment in Latin America and the Caribbean, 2005 (LC/G.2309-P), Santiago, Chile, May. United Nations publication, Sales No. E.06.II.G.44.

(2001), Foreign Investment in Latin America and the Caribbean, 2000 (LC/G.2125-P), Santiago, Chile, April. United Nations publication, Sales No. E.01.II.G.12.

Gallagher, K. and D. Chudnovsky (2009), Rethinking Foreign Investment for Sustainable Development. Lessons from Latin America, London, Anthem Press.

Girma, S., R. Kneller and M. Pisu (2005), "Export versus FDI: an empirical test", Review of World Economics, vol. 141, No. 2, Springer.

Godart, O., H. Görg and A. Hanley (2011), "Surviving the crisis: foreign multinationals vs domestic firms in Ireland", IZA Discussion Paper Series, No. 5882, Institute for the Study of Labour, Bonn, July.

Görg, H. and E. Strobl (2003), "Footloose' multinationals?", The Manchester School, vol. 71, No. 1, John Wiley \& Sons, January.

Hobday, M. and H. Rush (2007), "Upgrading the technological capabilities of foreign transnational subsidiaries in developing countries: the case of electronics in Thailand", Research Policy, vol. 36, No. 9, Amsterdam, Elsevier.

Koenker, R. (2005), Quantile Regression, New York, Cambridge University Press.

Kumar, N. (1990), "Mobility barriers and profitability of multinational and local enterprises in Indian manufacturing", The Journal of Industrial Economics, vol. 38, No. 4, Wiley, June.

Levinsohn, J. and A. Petrin (2003), "On the micro-foundations of productivity growth", November, unpublished.

Lipsey, R. (2002), "Home and host country effects of FDI", NBER Working Paper, No. 9293, Cambridge, Massachusetts, National Bureau of Economic Research, October.

Love, J.H., S. Roper and J. Du (2009), "Innovation, ownership and profitability", International Journal of Industrial Organization, vol. 27, No. 3, Amsterdam, Elsevier.

Marín, A. and V. Arza (2009), "The role of multinational corporations in innovation systems of developing countries. From technology diffusion to international involvement", Handbook of Innovation Systems and Developing Countries. Building Domestic Capabilities in a Global Context, B. Lundvall and others (eds.), Cheltenham, Edward Elgar.

Markusen, J.R. (2002), Multinational Firms and the Theory of International Trade, Cambridge, Massachusetts, The MIт Press.

Mata, J. and P. Portugal (2002), "The survival of new domestic and foreign-owned firms", Strategic Management Journal, vol. 23, No. 4, John Wiley \& Sons, April.

Moran, T., M. Graham and M. Blomström (2005), Does Foreign Direct Investment Promote Development?, Washington, D.C., Peterson Institute for International Economics.

Narula, R. and S. Lall (eds.) (2006), Understanding FDI-Assisted Economic Development, New York, Routledge.

Olley, S. and A. Pakes (1996), "The dynamics of productivity in the telecommunications industry", Econometrica, vol. 64, No. 6, New York, The Econometric Society. 
Ramstetter, E. (1998), "Comparisons of foreign multinationals and local firms in Asian manufacturing over time", Working Papers Series, vol. 98-18, Kitakyushu, The International Centre for the Study of East Asian Development.

Temouri, Y., N.L. Driffield and D. Higón (2008), "Analysis of productivity differences among foreign and domestic firms: evidence from Germany", Review of World Economics, vol. 144, No. 1, Springer.

UNCTAD (United Nations Conference on Trade and Development) (2005), World Investment Report 2005: Transnational
Corporations and the Internationalization of $R \& D$ (UNCTAD/ WIR/2005), Geneva, United Nations. United Nations publication, Sales No. E.05.II.D.10.

Van Biesebroeck, J. (2005), "Firm size matters: Growth and productivity growth in African manufacturing", Economic Development and Cultural Change, vol. 53, No. 3, Chicago, University of Chicago Press.

Wagner, J. (2007), "Exports and productivity: a survey of the evidence from firm-level data", The World Economy, vol. 30, No. 1 Wiley Blackwell. 